PROFESI (Profesional Islam)

Media Publikasi Penelitian; 2017; Volume 15; No 1.

Website: ejournal@stikespku.ac.id

\title{
Pengaruh Madu Terhadap Proses Penyembuhan Luka Gangren Pada Pasien Diabetes Mellitus
}

\author{
Nabhani ${ }^{*}$, Yuli Widiyastuti ${ }^{2}$, \\ ${ }^{1}$ Prodi DIII Keperawatan, Stikes PKU Muhammadiyah Surakarta \\ ${ }^{2}$ Prodi DIII Keperawatan, Stikes PKU Muhammadiyah Surakarta \\ 1nabhani@dosen.stikespku.ac.id \\ 2yuliwidyastuti@dosen.stikespku.ac.id
}

Kata Kunci
Diabetes mellitus,
Gangren,
Madu

Keywords

Diabetes mellitus,

Gangren,

Honey

\begin{abstract}
Abstrak
Diabetes mellitus adalah gangguan metabolisme yang ditandai dengan hiperglikemia yang berhubungan dengan abnormalitas metabolisme karbohidrat, lemak dan protein yang disebabkan oleh penurunan sekresi insulin atau penurunan sensitivitas insulin atau keduanya yang menyebabkan komplikasi kronis mikrovaskuler dan neuropati. Beberapa peneliti melakukan penelitian dengan metode pengobatan gangren secara herbal diantaranya yaitu dengan minyak zaitun, minyak kelapa, aloe vera dan madu. Madu sangat dipercaya oleh masyarakat untuk berbagai jenis pengobatan termasuk luka, madu juga mudah didapat selain itu efektif dalam proses penyembuhan luka. Luaran: 1. Publikasi ilmiah dalam Jurnal Nasional yang mempunyai ISSN, 2. Prosiding pada seminar ilmiah (berskala lokal, regional maupun nasional). Hasil Penelitian: Dari hasil uji data pairet $t$ tes hasil $t$ hitung 5.000 dan $p$ value 0.015 karena hasil $t$ hitung 5.000 diatas harga atau > table t: 2.35 dan $p<$ dari 0.05, maka disimpulkan ada manfaat madu untuk mempercepat proses penyembuhan luka gangrene sehingga hipotesis yang berbunyi ada manfaat madu terhadap penyembuhan luka gangrene di terima. Sementara kekuatan pengaruh atau manfaat dapat dilihat hasil Paired Samples Correlations dengan hasil 0.57 atau memiliki kekuatan 57 $\%$, sehingga dapat diketahui ada pengaruh yang sedang.
\end{abstract}

\section{The Effect of Honey Against Healing Process Gangrene Injury On Patient Diabetes mellitus}

\begin{abstract}
Diabetes mellitus is a metabolic disorder characterized by hyperglycemia associated with abnormalities of carbohydrate, fat and protein metabolism caused by decreased insulin secretion or decreased insulin sensitivity or both that leads to chronic microvascular complications and neuropathy. Some researchers do research with methods of gangrene treatment herbs such as with olive oil, coconut oil, aloe vera and honey. Honey is very trusted by the community for various types of treatment including wounds, honey is also easy to obtain moreover it is effective in the wound healing process. Outcomes: 1. Scientific publications in the National Journal that has ISSN, 2. Proceedings on scientific seminars (local, regional and national scale). Result of research: From test result data pairet $t$ test result $t$ count 5000 and $p$ value 0.015 because result $t$ count 5000 above price or > table t: 2.35 and $p$ <from 0.05, hence concluded there is benefit honey to accelerate healing process gangrene wound so that hypothesis which read there is benefit of honey on healing gangrene wound is received. While the power of influence or benefit can be seen from the result of Paired Samples Correlations with the result of 0.57 or have the power of 57\%, so it can be known there is a moderate influence.
\end{abstract}


PROFESI (Profesional Islam)

Media Publikasi Penelitian; 2017; Volume 15; No 1.

Website: ejournal.stikespku.ac.id

\section{PENDAHULUAN}

Diabetes mellitus adalah gangguan metabolisme yang ditandai dengan hiperglikemia yang berhubungan dengan abnormalitas metabolisme karbohidrat, lemak dan protein yang disebabkan oleh penurunan sekresi insulin atau penurunan sensitivitas insulin atau keduanya yang menyebabkan komplikasi kronis mikrovaskuler dan neuropati (Yuliana, 2009 dalam NANDA, 2013). Berbagai penelitian epidemiologi menunjukan adanya kecenderungan peningkatan insiden dan prevelensi Diabetes melitus tipe II di berbagai penjuru dunia termasuk Indonesia. WHO menyatakan kasus diabetes di Asia akan naik samapai 90\% dalam 20 tahun ke depan (Riskesdas, 2009). Di Indonesia berdasarkan hasil Riskedes (2009) dari 24417 responden berusia $>15$ tahun, 10,2\% mengalami toleransi glukosa terganggu (kadar glukosa) 140-200 mgdl setelah puasa selama 4 jam diberikan beban glukosa sebanyak 75 gram, Beberapa hal yang dihubungkan dengan faktor resiko diabetes melitus adalah obesitas, hipertensi, kurangnya aktivitas fisik dan rendahnya konsumsi sayur dan buah (Riskesdes, 2009). Berdasarkan laporan rumah sakit dan puskesmas, prevelensi diabetes mellitus tergantung insulin di Provinsi Jawa Tengah pada tahun 2008 sebesar 0.16 (Riskesdes, 2009).

Salah satu komplikasi yang sering terjadi adalah gangren, dimana kulit dan jaringan sekitar luka akan mati atau nekrotik dan mengalami pembusukan, Gangren dapat terjadi pada pasien bagian tubuh yang terendah diujung terutama pada ekstremitas bawah.

Perawatan luka biasanya mengunakan antiseptik cairan fisiologis ( $\mathrm{NaCl}$ atau $\mathrm{RL})$ lakukan debridement pada luka dan gunakan kasa steril serta peralatan luka Cloramfenikol, tetrasiklin HCL, silver sulvadiazine $1 \%$, basitracin, bioplacenton, mafenide acetate dan gentamisin sulfat adalah antibiotik yang sering penggunaan antibiotik topikal ini dapat menyebabkan efek yang merugikan seperti peningkatan jumlah koloni pada luka, menimbulkan nyeri dan sensitifitas terhadap sulfa (Moenadjat, 2006). Beberapa peneliti melakukan penelitian dengan metode pengobatan gangren secara herbal diantaranya pengobatan gangren dengan herbal yaitu dengan minyak zaitun (Hammad, 2012), madu (Hammad, 2013) dan aloe vera (Yunita Sari, 2015). Perawatan luka menggunakan aloe vera sebagai pengobatan luka pada gangren karena aloe vera mengandung anti inflamasi, antiseptik agen, glukoman dan aloe vera dapat me-ningkatkan sintesisi kolagen dan kontraksi pada luka (Yunitasari, 2015). Dari berbagai cara tersebut diatas pengusul memilih cara Perawatan luka menggunakan madu karena madu mengandung zat gula fruktosa dan glukosa yang merupakan jenis gula monosakarida yang mudah diserap oleh usus. Selain itu, madu mengandung vitamain, asam amino, mineral, antibiotik dan bahan-bahan aroma terapi. Pada umumnya madu tersusun atas $17,1 \%$ air, 82,4 \% karbohidrat total, $0,5 \%$ protein, asam amino, vitamin dan mineral. Selain asam amino nonesensial ada jug asam ami-no esensial diantaranya listin, hystadin, tritofan. Karbohidrat yang terkandung dalam madu termasuk tipe karbohidrat sederhana. Karbohidrat tersebut umumnya terdiri dari 38,5\% fruktosa dn $31 \%$ glukosa. Sisanya 12,9\% karbohidrat yang tersusun dari maltose, sukrosa, dan gula lain (Intanwidya, 2006 dalam Kartini, 2009). Kemudian cara perawatan luka gangren dengan madu secara rutin akan lebih baik, dari jaman dulu madu sangat dipercaya oleh masyarakat untuk berbagai jenis pengobatan termasuk luka madu juga mudah didapat selain itu efektif dalam proses penyembuhan luka karena kandungan airnya rendah, juga $\mathrm{PH}$ madu yang asam serta kandungan hidrogen peroxida-nya mampu membunuh bakteri dan mikro-organisme yang masuk kedalam tubuh kita. Selain itu madu juga mengandung antibiotika sebagai antibakteri dan antiseptik menjaga luka (Hammad, 2013).

\section{METODE PENELITIAN}

Metode yang digunakan adalah metode Quasi Eksperiment Design, disebut eksperimen jenis ini karena belum memenuhi persyaratan. Penelitian ini menggunakan pendekatan One Design Pre-test and Post-test Group, yaitu membandingkan subjek sebelum dan sesudah diberikan tindakan perawatan luka menggunakan madu 
Populasi dalam penelitian adalah seluruh pasien kunjungan di poliklinik omah luka sejumlah 20 dengan teknik Aksidental sampling. Instrumen menggunakan alat ukur DESIGN menurut Sugawa dkk, (2006) terdiri dari: check list. Data diambil pada bulan Mei sampai Juli 2017. Analisa menggunakan uji Paired t test pada signifikan 5\%.

\section{HASIL DAN PEMBAHASAN}

\subsection{Hasil}

Penelitaian dilakukan pada pasien yang berobat ke klinik omah luka mengalami komplikasi luka gangrene meliputi karakteristik responden (usia dan jenis kelamin), keadaan luka sebelum dan sesudah dilakukan tindakan kompres madu

\subsubsection{Karakteristik Responden berdasarkan Usia}

Tabel 1. Distribusi Frekuensi Responden Berdasarkan Usia

\begin{tabular}{lccc}
\hline No & Usia (tahun) & Frekuensi & Persentase $(\%)$ \\
\hline 1 & 57 & 1 & 25 \\
2 & 62 & 1 & 25 \\
3 & 67 & 1 & 25 \\
4 & 70 & 1 & 25 \\
\hline & Total & 4 & 100 \\
\hline
\end{tabular}

Tabel di atas memperlihatkan distribusi responden berdasarkan usia sebagian besar usia $>=60$ tahun (lansia) yaitu sebesar 3 orang $(75 \%)$.

\subsubsection{Karakteristik Responden berdasarkan Jenis Kelamin}

Tabel 2. Distribusi Frekuensi Responden Berdasarkan Jenis Kelamin

\begin{tabular}{llcc}
\hline No & Jenis Kelamin & Frekuensi & $\begin{array}{c}\text { Persentase } \\
(\%)\end{array}$ \\
\hline 1 & Laki-laki & 1 & 25 \\
2 & Perempuan & 3 & 75 \\
\hline & Total & 4 & 100 \\
\hline
\end{tabular}

Pada tabel di atas menunjukkan epidemiologi komplikasi gangrene pada diabetes mellitus sering terjadi pada perempuan $75 \%$ dibandingkan pada laki-laki hanya $25 \%$.

\subsubsection{Deskripsi Luka Responden}

Tabel 3. Deskripsi Luka Responden pada Perawatan Luka Menggunakan Kompres Madu pada Pengolahan Data, Dilakukan Hanya pada 4 Responden

\begin{tabular}{|c|c|c|c|c|c|c|c|c|c|c|}
\hline \multirow[t]{2}{*}{ No } & \multirow[t]{2}{*}{ Indikator } & \multicolumn{2}{|c|}{ Kasus 1} & \multicolumn{2}{|c|}{ Kasus 2} & \multicolumn{2}{|c|}{ Kasus 3} & \multicolumn{2}{|c|}{ Kasus 4} & \multirow{2}{*}{$\begin{array}{c}\operatorname{Max} \\
7\end{array}$} \\
\hline & & sbl & ssdh & sbl & ssdh & sbl & ssdh & sbl & ssdh & \\
\hline 1 & Depth/kedalaman luka & 5 & 2 & 4 & 2 & 4 & 1 & 5 & 3 & \\
\hline 2 & Exudate/eksudat & 2 & 1 & 3 & 1 & 2 & 1 & 4 & 3 & \\
\hline 3 & Size/luas luka & 3 & 2 & 3 & 2 & 3 & 2 & 4 & 3 & 6 \\
\hline 4 & Infection/infeksi & 3 & 1 & 2 & 1 & 3 & 1 & 4 & 3 & 6 \\
\hline 5 & $\begin{array}{l}\text { Granulasi tissue/jaringan } \\
\text { granulasi }\end{array}$ & 5 & 2 & 4 & 2 & 3 & 1 & 5 & 4 & 5 \\
\hline 6 & $\begin{array}{l}\text { Nekrotik tissue/jaringan } \\
\text { nekrotik }\end{array}$ & 3 & 1 & 3 & 1 & 2 & 1 & 3 & 2 & 7 \\
\hline & TOTAL & 21 & 9 & 19 & 9 & 17 & 7 & 25 & 18 & 6 \\
\hline
\end{tabular}


Pada tabel di atas dapat dilihat bahwa keadaan luka tergolong berat 2 (20-30) dan sedang 2 (10-19)

Tabel 4. Hasil Hasil Uji Distribusi Normal Luka Responden (One-Sample KolmogorovSmirnov Test)

$\begin{array}{clcc}\text { No } & \text { Luka } & \text { Nilai } p & \text { Keterangan } \\ 1 & \begin{array}{l}\text { Sblm } \\ \text { perlakuan }\end{array} & 0.846 & \begin{array}{c}0,05= \\ \text { normal }\end{array} \\ 2 & \begin{array}{l}\text { Stlh } \\ \text { perlakuan }\end{array} & 0,417 & \begin{array}{c}>0,05= \\ \text { normal }\end{array}\end{array}$

Pada tabel di atas menunjukkan data berdistribusi yang normal dan tidak normal yang ditunjukkan dengan membandingkan nilai $\mathrm{p}$ terhadap nilai $\mathrm{p}$ kritis yaitu 0,05 . karena lebih besar maka berdistribusi normal sehingga dilakukan uji parametris .

Hasil uji pengaruh madu terhadap proses penyembuhan gangrene Dengan paired $t$ tes hasil $\mathrm{t}$ hitung 5.000 dan $\mathrm{p}$ value 0.015 , hasil $\mathrm{t}$ hitung 5.000 diatas harga atau > table t: 2.35 dan $\mathrm{p}<$ dari 0.05 .

Hasi uji kekuatan pengaruh Paired Samples Correlations bahwa keeratan pengaruh paired sample correlation 0,577 (57\%) sehingga mempunyai pengaruh yang sedang

\subsection{Pembahasan}

Analisis univariat berdasar jenis kelamin responden 4 responden $75 \%$ wanita (3 orang) dan 25\% Laki-laki (1 orang) insiden tersebut senada dengan Hasil Riset Kesehatan Dasar (Riskesdas) 2013 yang baru dirilis Kementerian Kesehatan (Kemkes) obesitas pada perempuan cenderung lebih tinggi dibanding laki-laki. Perempuan meningkat dari $14,8 \%$ (2007) menjadi 32,9\% (2013), sedangkan laki-laki hanya $13,9 \%$ menjadi $19,7 \%$.

Berdasar umur dari 4 responden $75 \%$ berusia > 60 th yang golong lansia. Kondisi tersebut sesuai dengan prevalensi bahwa semakin usia lanjut kejadian penyakit semakin meningkat.

Karakteristik berdasar luka dari 4 kasus menurut skala design 2 kasus tergolong berat (skor > 20) dan 2 kasus tergolong sedang (skor < 20). Setelah dilakukan perawatan luka masingmasing kasus tidak memberikan respon yang sama hal ini banyak disebabkan oleh banyak factor antara lain kondisi luka itu sendiri, usia, nutrisi. Namun setelah dilakukan perawatan selama dua minggu secara umum terjadi perbaikan luka menjadi lebih bersih dan mengecil seperti hasil skala design rata-rata dari empat kasus dari skor 21 menjadi 11.

Dari analisis bivariat diperoleh hasil $\mathrm{t}$ hitung 5.000 dan $\mathrm{p}$ value 0.015 karena hasil $\mathrm{t}$ hitung 5.000 diatas harga atau > table t: 2.35 dan $\mathrm{p}<$ dari 0.05 , maka disimpulkan ada manfaat madu untuk mempercepat proses penyembuhan luka gangrene sehingga hipotesis yang berbunyi ada manfaat madu terhadap penyembuhan luka gangrene di terima. Dan keeratan pengaruh paired sample correlation 0,577 (57\%) sehingga mempunyai pengaruh yang sedang.

Seperti telah di jelaskan di bagian atas bahwa dari jaman dulu madu sangat dipercaya oleh masyarakat untuk berbagai jenis pengobatan termasuk luka, madu mengandung vitamain, asam amino, mineral, antibiotik dan bahan-bahan aroma terapi. Sehingga perawatan luka gangren dengan madu secara rutin akan lebih baik, madu juga mudah didapat selain itu efektif dalam proses penyembuhan luka karena kandungan airnya rendah, juga $\mathrm{PH}$ madu yang asam serta kandungan hidrogen peroxidanya mampu membunuh bakteri dan mikroorganisme yang masuk kedalam tubuh kita.

Dari hasil penelitian terhadap 4 kasus yang pengukurannya dilakukan sebelum dilakukan perawatan sebagai control dari kondisi luka yang relative tidak sama, terutama terhadap luka pada kasus 4 dengan kondisi luka yang cukup luas dan banyak jaringan nekrosis maka hasil akhir hanya terjadi perubahan yang sedikit dari skor 25 menjadi 18, sementara terhadap kasus 1-3 kondisi luka relative ringan sehingga pada akhir perawatan terjadi perubahan dan perbaikan luka yang cukup signifikan dengan rata-rata skor 19 menjadi 8 .

\section{SIMPULAN}

Luka gangrene merupakan komplikasi dari penyakit diabetes mellitus yang sering terjadi karena terjadi kerusakan pada pembuluh darah sehingga jaringan tidak cukup memperoleh aliran darah yang akhirnya terjadi nekrosis. Kondisi ini tindakan perawatan luka memerlukan waktu yang lama, hal ini terbukti dari hasil penelitian dari empat kasus setelah dilakukan perawatan dengan 
PROFESI (Profesional Islam) Media Publikasi Penelitian; 2017; Volume 15; No 1.

Website: ejournal@stikespku.ac.id

menggunakan kompres madu selama dua minggu walaupun memperlihatkan ada perbaikan luka tapi keadaan luka belum sembuh secara baik dan masih diperlukan perawatan lanjut.

Berdasar dari pembahasan kasus tersebut diatas dapat disimpulkan bahwa madu memiliki manfaat untuk membantu proses penyembuhan luka gangrene pasien diabetes mellitus, hasil uji data menggunakan paired $t$ test mendapatkan hasil t hitung 5.000 dan $\mathrm{p}$ value 0.015 karena hasil $\mathrm{t}$ hitung 5.000 diatas harga atau $>$ table $\mathrm{t}$ : 2.35 dan $\mathrm{p}<$ dari 0.05 , maka disimpulkan ada manfaat madu untuk mempercepat proses penyembuhan luka gangrene sehingga hipotesis yang berbunyi ada manfaat madu terhadap penyembuhan luka gangrene di terima.

Namun demikian penelitian ini masih terdapat keterbatasan seperti jumlah sample yang terbatas hanya 4 dengan kondisi luka yang relative tidak sama dan design penelitian tidak menggunakan variable control, sehingga kurang bisa mengukur secara akurat manfaat madu untuk proses penyembuhan luka.

\section{REFERENSI}

Hammad Said. 2012. 77 Resep Sehat dengan Minyak Zaitun. Indonesia: Aqwam.
2013.99 Resep Sehat dengan Madu.Indonesia: Aqwam

Intanwidya, Y. 2006. Analisa Madu dari Segi Kandunganya Berikut Khasiatnya Masingmasing. [serial online]. http://www.mailarchive.com/forum@alumniakabogor.net $/ \mathrm{msg} 01046 . \mathrm{html}$. diakses tanggal 5 Oktober 2015.

Moenadjat Y. 2006. Resusitasi: Dasar-dasar Manajemen Luka Bakar Fase Akut.

RISKESDAS. 2009. Laporan Hasil Riset Kesehatan Dasar (RISKESDAS). Nasional 2009. Jakarta: Badan Penelitian dan Pengembangan Kesehatan Departemen RI.

2013. Laporan Hasil Riset Kesehatan Dasar (RISKESDES). Nasional 2013. Jakarta: Badan Penelitian dan Pengembangan Kesehatan Departemen RI.

Yunitasari. 2015. Perawatan Luka Diabetes. Yogyakara: Graha Ilmu. 